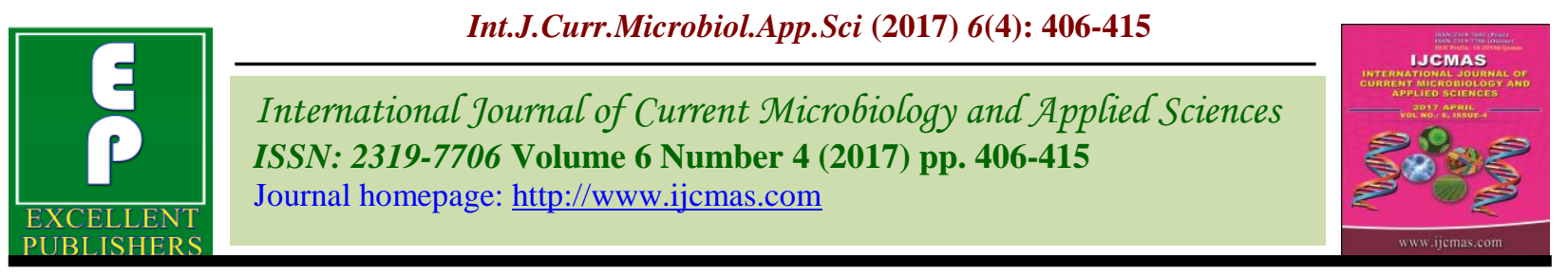

Original Research Article

https://doi.org/10.20546/ijcmas.2017.604.046

\title{
Studies on Effect of Sex and Age on Physico-Chemical and Organoleptic Qualities of Rajasri Chicken
}

\author{
N. Anitha Reddy ${ }^{1}$, K. Kondal Reddy ${ }^{2}$, M. Shashi Kumar ${ }^{1}$, \\ N. Krishnaiah ${ }^{3}$ and V. Kesava Rao ${ }^{1}$ \\ ${ }^{1}$ Department of Livestock Products Technology, C.V.Sc, PVNR TVU, Hyderabad, India \\ ${ }^{2}$ C.V.Sc, PVNR TVU, Hyderabad, India \\ ${ }^{3}$ Department of Veterinary Public Health and Epidemiology, C.V.Sc, PVNR TVU, \\ Hyderabad, India \\ *Corresponding author
}

\section{A B S T R A C T}

\begin{tabular}{|l|}
\hline Ke y w o r d s \\
Rajasri chicken, \\
Sex, Age, Breast, \\
Thigh, Physico- \\
chemical and \\
Organoleptic \\
qualities.
\end{tabular}

The present study was conducted to evaluate the effect of sex and age on physico-chemical and organoleptic qualities of Rajasri chicken at three different ages i.e. $16^{\text {th }}, 20^{\text {th }}$ and $24^{\text {th }}$ weeks of age. Day old chicks $(n=144)$ were reared to the age of 16,2024 weeks of age under the deep litter system. Six male and six females were slaughtered at 16, 20 and 24 weeks of age in each trail of total four trails. The thigh muscle showed significantly $(\mathrm{P}<0.05)$ higher $\mathrm{pH}$, Water Holding Capacity, myoglobin content, Muscle Fiber Diameter and Shear Force values than breast muscle and increased significantly $(\mathrm{P}<0.05)$ with an increase in age (from 16 to 24 weeks) in both sexes in the present study. Crude protein, crude fat and total ash percentages increased significantly $(\mathrm{P}<0.05)$ and moisture percent decreased significantly $(\mathrm{P}<0.05)$ with an increase in age (from 16 to 24 weeks) in both the muscles of either sex in the present study. Overall acceptability scores were found to be higher at $16^{\text {th }}$ week chicken compared to the subsequent age groups studied and slaughter of birds at 16 weeks of age is desirable among all the age groups studied which showed good palatability.

\section{Introduction}

Rajasri is a designer fowl suitable for backyard production developed by PV Narsimha Rao Telangana Veterinary University together with Poultry Research Station (PRS), Rajendranagar, Hyderabad. Rajasri variety is developed by crossing four different breeds (two dual type, one layer type exotic breed and local non-descript poultry were involved). It is different from other rural poultry varieties as it has a broad genetic base and introgressed with genes from local birds by incorporating desirable traits such as higher productivity (150-160 eggs per annum) compared to nondescript fowls under range conditions, Compact body and long shank length for agility to avoid predation, Capacity to withstand diseases and adverse climatic conditions and a truly dual purpose bird (Viroji Rao et al., 2012).

Most of the cases, people relish the meat from a country chicken than broilers probably due to a very varied diet and plenty of exercise and exposure to nature. In general, nutritive, 
physicochemical and sensory properties have been noted as the most crucial aspects in consumer perception of meat and meat products. Nutritive value is of great concern, but the physicochemical and organoleptic properties of meat are also important for meat processing and consumer acceptance.

The productive traits of Rajasri chicken have been studied by Viroji Rao et al., (2012) and Daida Krishna et al., (2012) but the meat quality has not been studied extensively. Hence, the present study was designed to evaluate the physico-chemical and organoleptic qualities of Rajasri chicken at three different ages $\left(16^{\text {th }}, 20^{\text {th }}\right.$ and $\left.24^{\text {th }}\right)$. (From 16 weeks age onwards the meat quality was studied as Rajasri is a slow growing chicken and attain minimum slaughter weights at this age).

\section{Materials and Methods}

\section{Experimental design}

Day old chicks were procured from Poultry Research Station (PRS) Rajendranagar, Hyderabad and reared in Department of Poultry Science to the ages of $16^{\text {th }}, 20^{\text {th }}$ and $24^{\text {th }}$ week, under deep litter system and actual farm conditions with identical management practices. Physico-chemical and organoleptic quality study was conducted in the Department of Livestock Products Technology, Hyderabad. A total number of 144 birds were slaughtered at 16, 20 and 24 weeks age. Four trials were conducted at each age, each trail consists of six male and six female. Meat samples were collected from the thigh and breast muscles after 24 hours of storage at refrigeration temperature $\left(4 \pm 1^{0} \mathrm{C}\right)$ to assess the physico-chemical and sensory attributes.

The $\mathrm{pH}$ of breast and thigh muscle samples was measured by adopting the procedure laid down by AOAC using a digital $\mathrm{pH}$ meter
(Elico model L 1-10 T, Chennai) with a glass probe electrode. About $10 \mathrm{~g}$ of meat sample was blended with $50 \mathrm{ml}$ of distilled water for one minute in a blender and the volume was made up to $100 \mathrm{ml}$ and $\mathrm{pH}$ was recorded. The estimation of water holding capacity (WHC) of breast meat was determined according to the method of Whiting et al., (1981). Breast and thigh sample of $500 \mathrm{mg}$ was taken and placed between the pre-weighed filter papers. Then it was placed on a rigid, flat surface by keeping polythene sheet above and below. A pressure (40 psi) i.e. $2.81 \mathrm{~kg}$ was applied to it for $5 \mathrm{~min}$. The meat flake was removed from the filter paper and weighed. The filter papers were dried and weighed. The percent WHC is estimated as the ratio between the weights of meat flake along with protein attached to the filter paper to the sample weight.

Muscle fiber diameter (MFD) was measured as per the method recommended by Jeremiah and Martin (1977). Breast and thigh sample of $5 \mathrm{~g}$ was cut into small cubes and homogenized for two 15 seconds periods at low speed, interspaced with a five second resting interval in a solution containing $0.25 \mathrm{M}$ sucrose and $1.0 \mathrm{mM}$ EDTA (Ethylene Di-amine Tetra Acetic acid) to produce slurry. One or two drops of the slurry were transferred onto a microscope slide and covered with a cover slip. The suspension was examined directly under a light microscopic equipped with low object and 10x eye piece containing a calibrated micrometer. MFD was measured as the mean cross sectional distance in micrometer between the exterior surfaces of the sarcolemma, at three different places along with its length of 20 randomly selected muscle fibers.

Breast and thigh muscle samples were sealed in low-density polyethylene bags and placed in water bath maintained at $100^{\circ} \mathrm{C}$ for $30 \mathrm{~min}$ with a final internal temperature of $80^{\circ} \mathrm{C}$, followed by overnight chilling at $4 \pm 1{ }^{\circ} \mathrm{C}$. Chilled samples were equilibrated to room 
temperature and $12 \mathrm{~mm}$ diametercores were taken using a tissue borer with muscle parallel to the direction of the fibres. The shear force of the core was measured using Texturometer (Model H1KF; Tinius Olsen, Redhill, England) with $\mathrm{V}$-shaped stainless steel blade $\left(60^{\circ}\right.$ angle) and triangular hole in the middle. The cores were sheared perpendicular to the muscle fiber orientation with 75 Newtons $(\mathrm{N})$ load range and a crosshead speed set at 200 $\mathrm{mm} / \mathrm{min}$. The force required to shear the samples was recorded in $\mathrm{N}$.

Myoglobin was extracted from meat using a modified procedure of Warris (1979). Breast and thigh samples were blended with 5 volumes of cold $0.04 \mathrm{M}$ phosphate buffer at pH 6.8 (prepared by adding Di-potassium hydrogen phosphate to Potassium dihydrogen phosphate until the buffer attains $\mathrm{pH}$ 6.8) and homogenized for 10 seconds and kept at $1{ }^{\circ} \mathrm{C}$ for $1 \mathrm{~h}$. That was centrifuged at $3500 \mathrm{rpm}$ at $4^{\circ} \mathrm{C}$ for $30 \mathrm{~min}$ and filtered through Whatman filter paper no.1. The absorbance of filtrate was measured at 525 and $700 \mathrm{~nm}$ using a UVVIS spectrophotometer (model: UV-1700; Pharma Spec, SHIMADZU, Japan). Myoglobin content estimated asMb $(\mathrm{mg} / \mathrm{g})=$ $\left(\mathrm{A}_{525}-\mathrm{A}_{700}\right) \times 2.303 \times 5$

The percentage of moisture, protein, fat and total ash were determined as per the methods recommended by A.O.A.C. (1980). Dry matter content was determined by ovendrying at $103^{\circ} \mathrm{C}$; total fat content was obtained by Soxhlet extraction using petroleum ether (B.P. $80-90^{\circ} \mathrm{C}$ ); Ash content was determined by charring fresh sample followed by heating in a muffle furnace for 3 to $5 \mathrm{~h}$ at $600^{\circ} \mathrm{C}$; Kjeldahal method was used for the analysis of total nitrogen content and crude protein content was calculated and expressed as percentage.

The organoleptic attributes viz. colour, flavour, juiciness and tenderness of cooked breast and thigh meat samples were assessed by subjecting to a semi- trained five-member panel drawn from the staff of the College of Veterinary Science, Hyderabad. Cooked cubes of approximately $1.5 \mathrm{~cm}$ cut from the breast and thigh muscles were served to the panel members as randomly coded samples and the panelists were provided with a nine point Hedonic score card to assess the colour, flavour, juiciness and tenderness of the sample.

\section{Statistical analysis}

The data was subjected to statistical analysis by applying two way ANOVA, Univariate analysis using statistical package for social sciences (SPSS) version 21. Differences between means were tested using Duncan's multiple comparison test and significance was set at $\mathrm{P}<0.05$ (Duncan, 1955).

\section{Results and Discussion}

The results (Table 1) reveal that the effect of age was significant $(\mathrm{P}<0.05)$ while the effect of sex was non-significant on $\mathrm{pH}$ of Rajasri chicken. Thigh muscle of both sexes showed significantly higher $\mathrm{pH}$ than breast muscle in present study. These results were corroborated with Souza et al., (2011) who observed ultimate $\mathrm{pH}$ of thigh muscle was higher compared to breast muscle and reported no significant effect of sex on ultimate $\mathrm{pH}$ in broilers. Sanka et al., (2014) attributed the higher thigh muscle $\mathrm{pH}$ might be due to higher muscle activities in leg muscles than breast muscle and observed a slightly higher $\mathrm{pH}$ of drumstick and thigh muscle at $7^{\text {th }}$ month than $5^{\text {th }}$ month, implied that, males were probably more active than female. Diaz et al., (2010) attributed the high $\mathrm{pH}$ of drumstick is probably due to the different type of muscles that predominate in drumstick (oxidative muscles Vs glycolytic muscles in the breast). Lonergan et al., (2003) and Abdullah et al., (2010) in broilers and Musa et al., (2006) in Anka and Rugao breeds 
observed no significant effect of sex on ultimate $\mathrm{pH}$ in broilers. At a $\mathrm{pH}$ of 5.4 to 6.2 the meat is normally considered to be of high quality (Bals, 2009; Woelfel et al., 2002).

The results (Table 2) showed that the effect of age was significant $(\mathrm{P}<0.05)$ while the effect of sex was non-significant on WHC of Rajasri chicken in the present study. These results were in accordance with the findings of Husak et al., (2008) who observed that higher meat $\mathrm{pH}$ is more effective for retaining desirable colour and moisture absorption properties and Muthukumar et al., (2011) reported that the WHC significantly increased with age in broilers. Musa et al., (2006) found no significant effect of sex on WHC of Anka and Rugao breeds. Lyon et al., (1985) reported an increase in WHC with an increase in age of broiler he attributed this to increase in fat content in broilers. Santiago et al., (2005) observed water holding properties of breast meat were significantly influenced by age at slaughter in broilers.

In the present study WHC was significantly higher in thigh muscle compared to breast muscle and increased with age which might be due to higher $\mathrm{pH}$ in thigh muscle as compared to breast muscle. The results (Table 3) reveal that the effect of sex and age were significant $(\mathrm{P}<0.05)$ on MFD of Rajasri chicken in the present study. These findings were similar to those of Berri et al., (2007) who reported an increase in breast muscle fiber diameter due to the reduced glycolytic potential of muscle fibers and correlated their finding with an increase in $\mathrm{pH}$ and WHC of muscle. Ono et al., (1993) and Muthukumar et al., (2011) reported significant increase $(41.51 \mu \mathrm{m}$ to $58.24 \mu \mathrm{m})$ in MFD with age in broilers. Wattanachant et al., (2005) reported the fiber diameter of Thai indigenous chicken at age 16 weeks in thigh muscle $(31.1 \mu \mathrm{m})$ was higher than breast muscle $(28.9 \mu \mathrm{m})$ and in contrary they observed opposite results in broilers i.e. thigh muscle $(20.4 \mu \mathrm{m})$ MFD was lower than breast muscle $(26.6 \mu \mathrm{m})$ and differences in muscle fiber diameter was attributed to the differences in age, rate of rigor onset, and degree of sarcomere shortening as suggested by Smith and Fletcher (1988). The results (Table 4) shows the effect of sex and age were significant $(\mathrm{P}<0.05)$ on the myoglobin content of Rajasri chicken in the present study. These findings were similar to the findings of Nishida and Nishida (1985) in chicken and Froning et al., (1968) in Turkey who observed the increase in myoglobin content with age. They also reported that male turkey myoglobin content was higher than female. Thigh muscle myoglobin content was more than the breast muscle of both sexes in the present study, which might be due to the predominance of type I fibers (oxidative) in thigh muscle as compared to type II fibers (glycolytic) in breast muscle as suggested by Lawrie (2006).

The results (Table 5) show the effect of sex and age were significant $(\mathrm{P}<0.05)$ on SFV of Rajasri chicken in the present study. In the present study the values of the shear force increased with age probably due to an increase in the cross linkages in the connective tissue. Collagen cross-linking increases with the age and is often associated with increased toughness (Fletcher, 2002). In the present study male showed comparatively lower shear force values than females and the results were corroborated with Simpson and Goodwin (1975) who reported that shear values for male broilers were significantly lower than those for females when the meat was cooked in an autoclave for $20 \mathrm{~min}$ and held for 2 to $4 \mathrm{~h}$ at $2^{\circ} \mathrm{C}$. These results are in contrary to the observations of Abdullah et al., (2010) and Musa et al., (2006) who reported male shear values were significantly higher than female. This variation in results might be due to cooked meat sample in present study Vs. fresh meat samples of earlier mentioned studies. 
Table.1 Effect of sex and age on $\mathrm{pH}-24 \mathrm{~h}$ of breast and thigh muscle of Rajasri chicken at three different ages

\begin{tabular}{ccccc}
\hline Sex & Muscle & 16 week & 20 week & 24 week \\
\hline Female & Breast & $5.65 \pm 0.02^{\mathrm{cB}}$ & $5.72 \pm 0.02^{\mathrm{bB}}$ & $5.79 \pm 0.01^{\mathrm{aB}}$ \\
& Thigh & $5.80 \pm 0.00^{\mathrm{bA}}$ & $5.83 \pm 0.02^{\mathrm{bA}}$ & $5.93 \pm 0.01^{\mathrm{aA}}$ \\
Male & Breast & $5.68 \pm 0.01^{\mathrm{bB}}$ & $5.74 \pm 0.01^{\mathrm{abB}}$ & $5.78 \pm 0.02^{\mathrm{aB}}$ \\
& Thigh & $5.78 \pm 0.01^{\mathrm{bA}}$ & $5.82 \pm 0.01^{\mathrm{bA}}$ & $5.91 \pm 0.02^{\mathrm{aA}}$ \\
\hline
\end{tabular}

Values are Mean \pm SE, $n=6$.

Means with different superscripts in a row (lower case letters) and in a column(Upper case letters) differ significantly $(\mathrm{P}<0.05)$

Table.2 Effect of sex and age on WHC (\%) of breast and thigh muscle of Rajasri chicken at three different ages

\begin{tabular}{lcccc}
\hline Sex & Muscle & 16 week & 20 week & 24 week \\
\hline Female & Breast & $19.08 \pm 0.05^{\mathrm{cB}}$ & $20.29 \pm 0.01^{\mathrm{bB}}$ & $21.17 \pm 0.03^{\mathrm{aA}}$ \\
& Thigh & $19.34 \pm 0.05^{\mathrm{cA}}$ & $21.75 \pm 0.01^{\mathrm{bA}}$ & $22.82 \pm 0.02^{\mathrm{aA}}$ \\
\multirow{2}{*}{ Male } & Breast & $19.09 \pm 0.02^{\mathrm{cB}}$ & $20.32 \pm 0.04^{\mathrm{bB}}$ & $21.15 \pm 0.01^{\mathrm{aB}}$ \\
& Thigh & $19.32 \pm 0.04^{\mathrm{cA}}$ & $21.77 \pm 0.02^{\mathrm{bA}}$ & $22.79 \pm 0.06^{\mathrm{aA}}$ \\
\hline
\end{tabular}

Values are Mean \pm SE $(n=6)$

Means with different superscripts in a row (lower case letters) and in a column

(Uppercase letters) differ significantly $(\mathrm{P}<0.05)$

Table.3 Effect of sex and age on Muscle Fiber Diameter $(\mu \mathrm{m})$ of breast and thigh muscle of Rajasri chicken at three different ages

\begin{tabular}{ccccc}
\hline Sex & Muscle & 16 week & 20 week & 24 week \\
\hline Female & Breast & $60.06 \pm 0.05^{\mathrm{Cb}}$ & $62.15 \pm 0.02^{\mathrm{bD}}$ & $63.86 \pm 0.04^{\mathrm{aB}}$ \\
& Thigh & $61.86 \pm 0.03^{\mathrm{cA}}$ & $65.80 \pm 0.01^{\mathrm{bB}}$ & $68.96 \pm 0.05^{\mathrm{aA}}$ \\
\multirow{2}{*}{ Male } & Breast & $60.12 \pm 0.12^{\mathrm{cB}}$ & $62.28 \pm 0.03^{\mathrm{bC}}$ & $63.93 \pm 0.06^{\mathrm{aB}}$ \\
& Thigh & $61.93 \pm 0.05^{\mathrm{cA}}$ & $65.93 \pm 0.04^{\mathrm{bA}}$ & $69.01 \pm 0.11^{\mathrm{aA}}$ \\
\hline
\end{tabular}

Values are Means \pm SE $(n=6)$

Means with different superscripts in a row (lower case letters) and in a column (Uppercase letters) differ significantly $(\mathrm{P}<0.05)$ 
Table.4 Effect of sex and age on Myoglobin $(\mathrm{mg} / \mathrm{g})$ of breast and thigh of Rajasri chicken at three different ages

\begin{tabular}{lcccc}
\hline Sex & Muscle & $\mathbf{1 6}$ week & 20 week & 24 week \\
\hline Female & Breast & $0.54 \pm 0.06^{\mathrm{cC}}$ & $0.72 \pm 0.03^{\mathrm{bD}}$ & $0.87 \pm 0.01^{\mathrm{aD}}$ \\
& Thigh & $1.16 \pm 0.07^{\mathrm{cB}}$ & $1.44 \pm 0.02^{\mathrm{bB}}$ & $1.71 \pm 0.03^{\mathrm{aB}}$ \\
Male & Breast & $0.66 \pm 0.01^{\mathrm{cC}}$ & $0.83 \pm 0.01^{\mathrm{bC}}$ & $1.03 \pm 0.03^{\mathrm{aC}}$ \\
& Thigh & $1.42 \pm 0.03^{\mathrm{cA}}$ & $1.68 \pm 0.02^{\mathrm{bA}}$ & $1.96 \pm 0.03^{\mathrm{aA}}$ \\
\hline
\end{tabular}

Values are Means \pm SE $(n=6)$

Means with different superscripts in a row (lower case letters) and in a column (Uppercase letters) differ significantly $(\mathrm{P}<0.05)$

Table.5 Effect of sex and age on Shear Force Value (N) of breast and thigh of Rajasri chicken at three different ages

\begin{tabular}{ccccc}
\hline Sex & Muscle & 16 week & 20 week & 24 week \\
\hline Female & Breast & $11.87 \pm 0.05^{\mathrm{cC}}$ & $12.68 \pm 0.05^{\mathrm{bC}}$ & $13.16 \pm 0.04^{\mathrm{aC}}$ \\
& Thigh & $13.21 \pm 0.11^{\mathrm{cA}}$ & $15.84 \pm 0.03^{\mathrm{bA}}$ & $22.57 \pm 0.04^{\mathrm{aA}}$ \\
Male & Breast & $10.04 \pm 0.03^{\mathrm{cD}}$ & $11.47 \pm 0.04^{\mathrm{bD}}$ & $12.83 \pm 0.05^{\mathrm{aD}}$ \\
& Thigh & $12.88 \pm 0.05^{\mathrm{cB}}$ & $15.08 \pm 0.04^{\mathrm{bB}}$ & $18.19 \pm 0.05^{\mathrm{aB}}$ \\
\hline
\end{tabular}

Values are Mean \pm SE $(n=6)$

Means with different superscripts in a row (lower case letters) and in a column (Uppercase letters) differ significantly $(\mathrm{P}<0.05)$

Table.6 Effect of sex and age on proximate composition of breast and thigh muscle of Rajasri chicken at three different ages

\begin{tabular}{ccccc}
\hline Parameter & Sex & 16 weeks & 20 weeks & 24 weeks \\
\hline Moisture \% & FB & $75.38 \pm 0.14^{\mathrm{aC}}$ & $74.30 \pm 0.12^{\mathrm{bB}}$ & $73.21 \pm 0.96^{\mathrm{cB}}$ \\
& FT & $76.08 \pm 0.05^{\mathrm{aB}}$ & $75.11 \pm 0.05^{\mathrm{bA}}$ & $74.25 \pm 0.13^{\mathrm{cA}}$ \\
& MB & $75.54 \pm 0.12^{\mathrm{aC}}$ & $74.42 \pm 0.15^{\mathrm{bB}}$ & $73.37 \pm 0.19^{\mathrm{Cb}}$ \\
Protein \% & MT & $76.42 \pm 0.25^{\mathrm{aA}}$ & $75.24 \pm 0.08^{\mathrm{bA}}$ & $74.32 \pm 0.14^{\mathrm{Ca}}$ \\
& FB & $21.23 \pm 0.17^{\mathrm{cA}}$ & $22.84 \pm 0.29^{\mathrm{bA}}$ & $23.54 \pm 0.20^{\mathrm{aA}}$ \\
& FT & $19.47 \pm 0.22^{\mathrm{cC}}$ & $20.80 \pm 0.31^{\mathrm{bB}}$ & $21.60 \pm 0.16^{\mathrm{aC}}$ \\
Fat \% & MB & $21.48 \pm 0.17^{\mathrm{cA}}$ & $22.97 \pm 0.16^{\mathrm{bA}}$ & $24.01 \pm 0.14^{\mathrm{aA}}$ \\
& MT & $20.26 \pm 0.21^{\mathrm{cB}}$ & $21.31 \pm 0.16^{\mathrm{bB}}$ & $22.31 \pm 0.16^{\mathrm{aB}}$ \\
& FB & $1.06 \pm 0.02^{\mathrm{bC}}$ & $1.21 \pm 0.07^{\mathrm{bC}}$ & $1.43 \pm 0.09^{\mathrm{aC}}$ \\
& FT & $1.82 \pm 0.11^{\mathrm{bA}}$ & $2.09 \pm 0.07^{\mathrm{bA}}$ & $2.81 \pm 0.12^{\mathrm{aA}}$ \\
& MB & $0.99 \pm 0.02^{\mathrm{cC}}$ & $1.12 \pm 0.02^{\mathrm{bC}}$ & $1.22 \pm 0.03^{\mathrm{aC}}$ \\
& MT & $1.44 \pm 0.04^{\mathrm{cB}}$ & $1.84 \pm 0.04^{\mathrm{bB}}$ & $2.20 \pm 0.05^{\mathrm{aB}}$ \\
& FB & $1.08 \pm 0.02^{\mathrm{bAB}}$ & $1.20 \pm 0.07^{\mathrm{abAB}}$ & $1.32 \pm 0.05^{\mathrm{aA}}$ \\
& FT & $0.85 \pm 0.04^{\mathrm{cC}}$ & $1.04 \pm 0.05^{\mathrm{bB}}$ & $1.20 \pm 0.01^{\mathrm{aB}}$ \\
& MB & $1.12 \pm 0.04^{\mathrm{cA}}$ & $1.25 \pm 0.02^{\mathrm{bA}}$ & $1.38 \pm 0.01^{\mathrm{aA}}$ \\
& MT & $0.99 \pm 0.03^{\mathrm{cB}}$ & $1.11 \pm 0.02^{\mathrm{bAB}}$ & $1.29 \pm 0.02^{\mathrm{aAB}}$ \\
\hline
\end{tabular}

FB: female breast, FT: female thigh, MB: male breast, MT: male thigh.

Values are Mean \pm SE; $(n=6)$.

Means with different superscripts in a row (lower case letters) and in a column

(Upper case letters) differ significantly $(\mathrm{P}<0.05)$ 
Table.7 Effect of sex and age on organoleptic scores of breast and thigh muscle of Rajasri chicken at three different ages

\begin{tabular}{ccccc}
\hline Parameter & Sex & $\mathbf{1 6}$ weeks & 20 weeks & 24 weeks \\
\hline Colour & FB & $6.50 \pm 0.01^{\mathrm{cD}}$ & $6.65 \pm 0.02^{\mathrm{bD}}$ & $6.89 \pm 0.02^{\mathrm{aC}}$ \\
& FT & $6.80 \pm 0.02^{\mathrm{cB}}$ & $6.91 \pm 0.02^{\mathrm{bB}}$ & $7.14 \pm 0.03^{\mathrm{aB}}$ \\
& MB & $6.65 \pm 0.02^{\mathrm{cC}}$ & $6.78 \pm 0.01^{\mathrm{bC}}$ & $6.92 \pm 0.01^{\mathrm{aC}}$ \\
Juiciness & MT & $7.05 \pm 0.04^{\mathrm{bA}}$ & $7.18 \pm 0.03^{\mathrm{aA}}$ & $7.23 \pm 0.01^{\mathrm{aA}}$ \\
& FB & $6.54 \pm 0.03^{\mathrm{cC}}$ & $6.70 \pm 0.00^{\mathrm{bC}}$ & $6.86 \pm 0.03^{\mathrm{aC}}$ \\
& FT & $6.69 \pm 0.02^{\mathrm{bAB}}$ & $6.79 \pm 0.03^{\mathrm{bB}}$ & $7.05 \pm 0.06^{\mathrm{aB}}$ \\
& MB & $6.63 \pm 0.01^{\mathrm{cB}}$ & $6.74 \pm 0.02^{\mathrm{bBC}}$ & $6.92 \pm 0.01^{\mathrm{Ac}}$ \\
Tenderness & MT & $6.74 \pm 0.02^{\mathrm{cA}}$ & $6.84 \pm 0.02^{\mathrm{bA}}$ & $7.16 \pm 0.02^{\mathrm{aA}}$ \\
& FB & $7.24 \pm 0.01^{\mathrm{aA}}$ & $7.16 \pm 0.01^{\mathrm{bA}}$ & $7.02 \pm 0.03^{\mathrm{cA}}$ \\
& FT & $6.97 \pm 0.07^{\mathrm{aC}}$ & $6.85 \pm 0.01^{\mathrm{bC}}$ & $6.72 \pm 0.01^{\mathrm{bC}}$ \\
Flavor scores & MB & $7.11 \pm 0.02^{\mathrm{aB}}$ & $7.03 \pm 0.03^{\mathrm{abB}}$ & $6.92 \pm 0.05^{\mathrm{bB}}$ \\
& MT & $6.76 \pm 0.02^{\mathrm{aD}}$ & $6.63 \pm 0.02^{\mathrm{bD}}$ & $6.56 \pm 0.02^{\mathrm{bD}}$ \\
& FB & $6.54 \pm 0.01^{\mathrm{cD}}$ & $6.69 \pm 0.02^{\mathrm{bC}}$ & $6.78 \pm 0.02^{\mathrm{aD}}$ \\
& FT & $6.75 \pm 0.01^{\mathrm{bB}}$ & $6.82 \pm 0.01^{\mathrm{bB}}$ & $6.98 \pm 0.04^{\mathrm{aB}}$ \\
OCverall & MB & $6.62 \pm 0.02^{\mathrm{cC}}$ & $6.73 \pm 0.01^{\mathrm{bC}}$ & $6.89 \pm 0.02^{\mathrm{aC}}$ \\
& MT & $6.84 \pm 0.01^{\mathrm{cA}}$ & $7.09 \pm 0.02^{\mathrm{bA}}$ & $7.26 \pm 0.01^{\mathrm{aA}}$ \\
& FB & $6.93 \pm 0.01^{\mathrm{aB}}$ & $6.87 \pm 0.01^{\mathrm{bAB}}$ & $6.81 \pm 0.02^{\mathrm{bA}}$ \\
& FT & $7.05 \pm 0.03^{\mathrm{aA}}$ & $6.94 \pm 0.01^{\mathrm{bA}}$ & $6.82 \pm 0.01^{\mathrm{cA}}$ \\
& MB & $6.95 \pm 0.01^{\mathrm{aB}}$ & $6.82 \pm 0.01^{\mathrm{bB}}$ & $6.79 \pm 0.01^{\mathrm{bA}}$ \\
& MT & $7.09 \pm 0.02^{\mathrm{aA}}$ & $6.90 \pm 0.03^{\mathrm{bA}}$ & $6.84 \pm 0.01^{\mathrm{bA}}$ \\
\hline
\end{tabular}

FB: female breast, FT: female thigh, MB: male breast, MT: male thigh.

Values are Mean $\pm S E$; $(n=6)$. Means with different superscripts in a row (lower case letters) and in a column (upper case letters) differ significantly $(\mathrm{P}<0.05)$

The lower shear force values in the present study may be due to the fact that the shear force values were obtained after $24 \mathrm{~h}$ aging, which is in accordance with the study of Abdullah et al., (2010) who reported a decrease in shear value $(50.7 \mathrm{~N}$ to $20.5 \mathrm{~N}$ in a period of $0 \mathrm{~h}$ to the $24 \mathrm{~h}$ period of aging time in broiler breast) with increase in aging period.

The results (Table 6) reveal that the effect of sex and age were significant $(\mathrm{P}<0.05)$ on percent moisture, crude protein, crude fat and total ash of Rajasri chicken in the present study. The moisture percent decreased significantly $(\mathrm{P}<0.05)$ with age where crude protein, crude fat and total ash percentage increased. These results are in accordance with Muthukumar et al., (2011) who reported a significant decrease in moisture percentage, the increase in crude protein and crude fat percent with age in broilers. In contrary to the present study, they reported an insignificant effect of age on ash percent. Fakolade (2015) reported a significant decrease in moisture percent, increase in protein and ash percent, in contrary to the present study, they have reported a significant $(\mathrm{P}<0.05)$ decrease in crude fat percent with age in Harco Black chicken. In the present study moisture percent and crude fat percent was higher in thigh muscle compared to breast muscle where crude protein and total ash percent was higher in breast muscle in both the sexes. These findings were corroborated with Fakolade (2015), Jaturasitha et al., (2008), Intarapichet et al., (2008) and Haunshi et al., (2013). In 
the present study moisture percent was insignificant between male breast and female breast muscle, but the thigh moisture percentage was higher in male only at 16 weeks of age. Protein percent was higher in male than female in both muscles, crude fat percent was higher in female in both muscles and ash percentage was higher in male. In contrary to these findings Lopez et al., (2011) reported an insignificant effect of sex on proximate composition in broilers.

The results (Table 7 ) revealed the effect of sex and age were significant $(\mathrm{P}<0.05)$ on colour, juiciness, tenderness and flavor scores of Rajasri chicken in the present study. The mean colour scores increased with age and higher scores were observed in males than females. Thigh muscle colour scores were higher than female, this might be due to differences in myoglobin content of muscle. Thigh muscle showed a higher juiciness score than breast muscle, this might be due to high fat content of thigh, male showed comparatively a higher juiciness score than female this might be due to differences in WHC of muscle. These findings were in accordance with Hocquette et al., (2010). Tenderness scores decreased with age, this might be due to an increase in fiber diameter, connective tissue and cross linkages between polypeptide chains with the advancement of age. Generally, flavor components are related to the fat content and flavor scores increase with age. The effect age was significant $(\mathrm{P}<0.05)$ while sex was non-significant on the overall acceptability score of Rajasri chicken in the present study. Overall acceptability was highest in male thigh, which might be due to good flavor of thigh muscle besides tenderness in muscles. Overall acceptability was decreased with age and higher at 16 weeks age, this might be due to the effect of decreased tenderness with age, which is an important factor in sensory evaluation of chicken meat.
In conclusion sex and age have shown significant $(\mathrm{P}<0.05)$ effect on physicochemical and organoleptic qualities of Rajasri chicken. The palatability is more at 16 weeks of age among all three age groups studied and the male bird showed significantly $(\mathrm{P}<0.05)$ high performance than female. It is recommended that slaughter of Rajasri bird at 16 weeks can be considered more honest as per results obtained in the present work.

\section{Acknowledgments}

The authors are thankful to the Department of Poultry Science for the facilities provided to rear the birds. The Associate Dean, College of Veterinary Science, Rajendranagar, Hyderabad is duly acknowledged for providing necessary financial and infrastructure facilities for this study.

\section{References}

A.O.A.C. 1980. Official Methods of Analysis, 13th ed. Association of Official Analytical Chemists, Washington D.C. 376-384.

Abdullah, A.Y. and Matarneh, S.K. 2010. Broiler performance and the effects of carcass weight, broiler sex, and post chill carcass aging duration on breast fillet quality characteristics. J. App. Poultry Res., 19: 46-58.

Bals, C. 2009. Quality of Poultry meat and factors that define it. University of Oradea, Faculty of Environmental Protection, 26 Gen. Magheru St. 410048 Oradea.

Berri, C., Le Bihan-Duval, E., Debut, M., Sante-Lhoutellier, V., Baeza, E., Gigaud, V., Jego, Y. and Duclos, M.J. 2007. Consequence of muscle hypertrophy on characteristics of Pectoralis major muscle and breast meat quality of broiler chickens. J. Anim. Sci., 85: 2005-2011. 
Daida Krishna, Rama rao, S.V., Prakash, B. and ChinniPreetham, V. 2012. Growth Performance and Survivability of Rajasri Birds under Deep Litter and Scavenging Systems. Int. J. Poult. Sci., 11(10): 621-623.

Diaz, O., Rodriguez, L., Torres, A. and Cobos. 2010. Chemical composition and physico-chemical properties of meat from capons as affected by breed and age. Span. J. Agric. Res., 8(1): 9199.

Duncan, D.B. 1955. Multiple ' $F$ ' test. Biometrics, 1: 142.

Fakolade, P.O. 2015. Effect of age on physico-chemical, cholesterol and proximate composition of chicken and quail meat. Afr. J. Food Sci., 9(4): 182186.

Fletcher, D.L. 2002. Poultry meat quality. World Poult. Sci J., 58(2): 131-145.

Froning, G.W., Daddarid, J. and Hartung, T.E. 1968. Color and myoglobin concentration in turkey meats as effected by age, sex, and strain. Poult. Sci., 47: 1827-1836.

Haunshi, S., Sunitha, R., Shanmugam, M., Padhi, M.K. and Niranjan, M. 2013. Carcass characteristics and chemical composition of breast and thigh muscles of native chicken breeds. Indian $J$. Poult. Sci., 48(2): 219-222.

Hocquette, J.F., Gondret, F., Baéza, E., Médale, F., Jurie, C. and Pethick, D.W. 2010. Intramuscular fat content in meatproducing animals: development, genetic and nutritional control, and identification of putative markers. Animal, 4(2): 303-319.

Husak, R.L., Sebrane, J.G. and Bregendahl, K.K. 2008. A survey of commercially available broilers marketed as organic, free-range and conventional broilers for cooked meat yields, meat composition and relative value. Poult. Sci., 87: 23672376 .
Intarapichet, K., Suksombat, W. and Maikhunthod, B. 2008. Chemical compositions, fatty acid, collagen and cholesterol contents of Thai hybrid native and broiler chicken meats. $J$. Poult Sci., 45: 7-14.

Jaturasitha, S., Srikanchai, T., Kreuzer, M. and Wicke, M. 2008. Differences in carcass and meat characteristics between chicken indigenous to Northern Thailand (Black-Boned and Thai Native) and imported extensive breeds (Bresse and Rhode Island Red). Poult. Sci., 87: 160-169.

Jeremiah, L.E. and Martin, A.H. 1977. Effect of rigor chilling and freezing and sub cutaneous fat cover upon the histological and shear properties of bovine longissimusdorsi muscle. Can. J. Anim. Sci., 62: 353.

Lawrie, R.A. and Ledward, D.A. 2006. Meat Sci., $7^{\text {th }}$ Edn. Wood head Publishing Limited.

Lonergan, S.M., Deeb, N., Fedler, C.A. and Lamont, S.J. 2003. Breast meat quality and composition in unique chicken populations. Poult. Sci., 82: 1990-1994.

Lopez, K.P., Schilling, M.W. and Corzo, A. 2011. Broiler genetic strain and sex effects on meat characteristics. Poult. Sci., 90: 1105-1111.

Lyon, C.E., Hamm, D., Thomson, J.E. and Hudspeth, J.P. 1985. The Effects of Holding Time and Added Salt on $\mathrm{pH}$ and Functional Properties of Chicken Meat. Poult. Sci., 64: 307.

Musa, H.H., Chen, G.H., Cheng, J.H., Li, B.C. and Mekki, D.M. 2006. Study on carcass characteristics of chicken breeds raised under the intensive condition. Int. J. Poult. Sci., 5: 530-33.

Muthukumar, M., Sen, A.R., Naveena, B.M., Vaithiyanathan, S. and Patil, S.G. 2011. Carcass traits and meat quality attributes of broilers grown to different body weights. Indian J. Anim. Sci., 
81(6): 615-620.

Nishida, J. and Nishida, T. 1965. Relationship between the concentración of myoglobin and parvalbumin in various types of muscle tissue from chickens. Br. Poult. Sci., 26:105-115.

Ono, Y., Iwamoto, H. and Takahara, H. 1993. The relationship between muscle growth and the growth of different fiber types in the chicken. Poult. Sci., 72: 568-576.

Owens, C.M., Hirschler, E.M., McKee, S.R., Martinez-Dawson, R. and Sams, A.R. 2000. The characterization and incidence of pale, soft, exudative turkey meat in a commercial plant. Poult. Sci., 79: 553-558.

Sanka, Y.D. and Mbaga, S.H. 2014.Evaluation of Tanzanian local chicken reared under intensive and semi-intensive systems: II. Meat quality attributes. Livestock Res. Rural Develop., Volume 26.

Santiago, H.L., Denbow, D.M., Emmerson, D.A., Denbow, C., Graham, P. and Hohenboken, W. 2005. Effects of strain, plane of nutrition, and age at slaughter on performance and meat quality traits of broilers. Poult. Sci., 84(1): 128.

Simpson, M.D. and Goodwin, T.L. 1975. Tenderness of broilers as affected by processing plants and seasons of the year. Poult. Sci., 54: 275-279.

Smith, D.P. and Fletcher, D.L. 1988. Chicken breast muscle fiber type and diameter as influenced by age and intramuscular location. Poult. Sci., 67: 908-913.

Souza, X.R., Faria, P.B. and Bressan, M.C. 2011. Proximate composition and meat quality of broilers reared under different production system. Braz. J. Poultry Sci., 13(1): 15-20.

Viroji Rao, S.T., Chinni Pretham, V., Shakunthala Devi, K. and Narasimha, J. 2012. Rajasri - a designer fowl introgressed with genes from native birds evolved for backyard production system. Indian J. Poult. Sci., 47(3): 388-390.

Warris, P.D. 1979. The extraction of haeme pigments from fresh meat. J. Food Technol., 14: 75-80.

Wattanachant, S., Benjakul, S. and Ledward, D.A. 2005. Microstructure and thermal characteristics of Thai indigenous and broiler chicken muscles. Poult. Sci., 84: 328-336.

Whiting, R.C. and Jenkins, R.K. 1981. Comparison of Rabbit, Beef and Chicken meats for functional properties and frankfurter processing. $J$. Food Sci., 46: 1693-1696.

Woelfel, R.L., Owens, C.M., Hirschler, E.M., Martinez-Dawson, R. and Sams, A. R.2002. The characterization and incidence of pale, soft, and exudative broiler meat in a commercial processing plant. Poult. Sci., 81: 579-584.

\section{How to cite this article:}

Anitha Reddy, N., K. Kondal Reddy, M. Shashi Kumar, N. Krishnaiah and V. Kesava Rao. 2017. Studies on Effect of Sex and Age on Physico-Chemical and Organoleptic Qualities of Rajasri Chicken. Int.J.Curr.Microbiol.App.Sci. 6(4): 406-415. doi: https://doi.org/10.20546/ijcmas.2017.604.046 